\title{
Determination of Postharvest Pod Storage on Viability and Seedling Growth Performance of Cocoa (Theobroma cacao L) in the Nursery
}

\author{
Joseph Kofi Saajah $^{1} \&$ Bonaventure Kissinger Maalekuu ${ }^{2}$ \\ ${ }^{1}$ Cocoa Swollen Shoot Virus Disease Control Unit (CSSVDCU), Ghana Cocoa Board (COCOBOD), Ghana \\ ${ }^{2}$ Department of Horticulture, Kwame Nkrumah University of Science \& Technology, Kumasi-Ghana), Ghana \\ Correspondence: Joseph Kofi Saajah, Cocoa Swollen Shoot Virus Disease Control Unit (CSSVDCU), Ghana \\ Cocoa Board (COCOBOD), COCOBOD Building, Dunkwa-on-Offin. P. O. Box 197, Dunkwa, Ghana. Tel: \\ 233-20-381-4890/24-484-7449. E-mail: jksaajah@yahoo.com
}

Received: January 14, 2014 Accepted: February 17, 2014 Online Published: March 15, 2014

doi:10.5539/jas.v6n4p77 URL:http://dx.doi.org/10.5539/jas.v6n4p77

\begin{abstract}
This research was conducted to determine how cocoa pod storage affects seed viability, when stored in containers for a specific period. The objectives were to determine the maximum storage period for maximum seed viability, determine the ideal storage container for maximum germination and finally determine the superior growth performance of the seedlings obtained. The design was a Randomized Complete Block Design (RCBD) in a factorial arrangement involving two factors: storage period and storage container. This arrangement produced interactions between the two factors and increased precision due to "Hidden replication". Podwere randomly drawn at 5 daily intervals and seed sowed to determine viability through sixteen (16) parameters, which included time to start and end germination, germination percentage, stem girth, canopy spread, shoot length and vigour index. The results generated from this experiment were in respect of interactions and simple effects of the two factors, on viability and seedling growth performance. Interaction effects were pronounced on five parameters which included time taken to start and end germination; vigour index; shoot height and leaf area. Germination speed and percentage were also significantly influenced by storage period. For growth parameters, superior performance $(\mathrm{p}<0.05)$, was obtained for variables such as leaves per plant, petiole length, internode length, within 1 day of harvest (DOH)-15 days after harvest (DAH) period. In respect of the type of container used for storage, internode length and dry matter accumulation were significantly influenced. Storage temperature and relative humidity did not affect the results. Pods stored from 1-15 DAH in basket, jute sack or fertilizer sack had maximum viability.
\end{abstract}

Keywords: hidden-replication, significant, factorial arrangement, variable/parameter, viability, interactions, vigour, storage

\section{Introduction}

Cocoa (Theobroma cacao) is a member of the family Sterculiacae and genus Theobroma which is divided into six groups containing twenty-two species among which Theobroma cacao is widely cultivated (Opoku-Ameyaw \& Baah, 2010).

The Ghanaian economy continues to receive great foreign exchange earnings from this commercial crop known as "The Golden Pod". According to the Institute of Statistical, Social and Economic Research (ISSER), University of Ghana (2003), in the year 2002, cocoa made up $22.4 \%$ (463 million US \$) of the total foreign exchange earnings of Ghana and also constituted $63 \%$ of the foreign export earnings from the agricultural sector of the country.

The quality of seed or bean for propagation was better when the cocoa pod completes structural and functional development and attains physiological maturity on the plant itself (Opoku-Ameyaw et al., 2010). Seed viability maintenance especially under storage, and their nursery and / or field performance has been crucial to the sustenance of Ghana's cocoa industry dominated by smallholder farmers, which problem, was first investigated for a limited storage period of one (1) week and by Ahenkora and Halm (1977). The current study is important in the present context, because storage of pods for most farmers in Ghana goes beyond the one week period previously assessed as a result of crucial social engagement of smallholder Ghanaian farmers (unpublished Smallholder Cocoa Farmer Survey Report in Ghana, 2012). The previous study did not also assess the effect of traditional 
cocoa pod storage containers on the viability of the seed, which the current study seeks to investigate. Cocoa seed planting is seasonal, and since cocoa pods are unavailable to all farmers at the appropriate time for raising seed nurseries, the storage of pods beyond one week period has become inevitable for the farmer, the seed producer (Seed Production Unit of COCOBOD) and the breeder as the case may be, in an attempt to increase the area under cocoa production in order to increase cocoa production for increased returns. This ultimately calls for acquisition and proper management of planting materials (cocoa pods), which in Ghana is provided only by 26 seed gardens (cocoa stations) under COCOBOD (Opoku-Ameyaw et al., 2010).

Despite the need for pod storage as briefly outlined above, it is quite a natural phenomenon that cocoa seed loses its viability and vigour under storage (both within thepod and scoopedfresh beans/ seed), as any other biological material does. The deterioration, which is quite impossible to completely control, is a function of storage environment conditions and the length of handling or storage, resulting in low germination of the seed from such pods.

This concern notwithstanding, major studies into the postharvest quality of cocoa (except by Ahenkora \& Halm's short period study in 1977) have been in the area of processed cocoa beans as raw materials for industrial processing purposes. Not much work has been done in terms of postharvest pod management for subsequent propagation, to help farmers achieve efficiency in their production enterprise.

It is therefore hoped that this study would impact positively on management of Ghana's cocoa industry, as well as other tropical countries which produce cocoa, towards a sustainable cocoa industry.

Specifically, the outcome of the study will augment the very little knowledge on the subject and catalyze the needed attention towards postharvest management of pods for the overall academic well-being of tropical cocoa producing countries. In addition, the findings of the study will be expected to help in informed-decision and policy making in the area of creation and distribution of more Seed Gardens to serve the larger interest of all stakeholders in Ghana's cocoa industry.

Finally, it is hoped that the study will stimulate interest in the academia of Cocoa Research for further studies in cocoa pod management after harvest.

According to work done by Redshaw (1965), germination capacity of cocoa appears to be short lived, and that viability is lost within 10-15 days after the seeds are harvested, unless they are placed under special storage conditions which permit their germination.

However in most tropical countries in Africa, methods of storage was to maintain seeds within pods and this has remained the main form of storage to date, without any special storage structure (Onakoya, 2011). He indicated that Cocoa seeds readily germinate without dormancy when sowed but lose viability on extraction from the pod within five to seven days, unless specially treated, which treatment may involve mixing seed with moist fine sand, moist sawdust or moist ground charcoal and leaving the mixture in a cool dry place, for which the extracted seeds can be stored for two to three weeks and still retain their viability.

Ahenkora and Halm (1977) in their study asserted that cocoa pods heaped in the nursery should be broken and sown within nine days after harvest, but that viability was maximum when storage was for six days after harvest, and hypothesized that viability could decline rapidly, thereafter. Subsequent to this assertion, whole cocoa pods exported to Liberia by the Seed Production Unit of COCOBOD in 2009 recorded an unsatisfactory low germination percentage when the seed were extracted and planted upon arrival (SPU Unpublished Report, 2009).

Reference to storage containers for seed and pod, Robbins and Shetha (1986) prescribed that un-extracted fruit seeds (as in cocoa pods in the tropics) should not be stored in sealed containers or in deep piles. Subsequently, Oti-Boateng(2001) and Agrawal (1995) categorized packaging/ storage materials into three: (1) moisture-vapour permeable containers (e.g. jute sack); (2) moisture-vapour resistant containers (e.g. Jute lined with polythene film); and (3) moisture-vapour proof containers (tin cans, polythene), which has been the basis of selecting storage containers for agricultural produce in Ghana.

In respect of this, a storage experiment was conducted to ascertain the storage potential of cocoa pods /seed for a period of up to thirty (30) days and assessed at five (5) daily intervals, under ambient storage conditions at Appiadu, near KNUST, Kumasi, among other objectives to: determine the maximum storage period for which pods can be stored for maximum seed viability, determine the ideal storage container within which pods can be stored for maximum germination and finally determine the superior growth performance parameters exhibited by seedlings obtained from the above storage procedure, which ultimately provided the basis for answering the following questions asked: 
What is the maximum allowable number of days that cocoa pods can stay to give maximum germination percentage? Which traditional storage material used by farmers for carting and storing cocoa pods will produce maximum germination percentage? How can postharvest management/ storage of pods be improved to further enhance seed viability?

\section{Materials and Methods}

The design of this research is a Randomized Complete Block Design (RCBD) in a factorial arrangement involving two factors: effects of storage period and the effects of storage container. The Factorial arrangement helped save time and obtained the interactions between the two factors, increased precision due to so-called "Hidden replication". With a factorial arrangement, experimental rates can be applied over a wider range of condition (Anonymous).

This storage experiment was conducted on Hybrid Cocoa variety with different pod storage periods/ duration to ascertain their influence on viability/germination under ambient storage conditions. During the period November 2012-March 2013. The details of materials used and the techniques adopted during the course of this investigation are explained below:

\subsection{Experimental Site and Climatic Condition}

The research was conducted at Appeadu, near KNUST, Kumasi, which lies between Latitude $6^{\circ} 745^{\prime} \mathrm{N}$ and longitude $01^{\circ} 36^{\prime} \mathrm{W}$ (Anon, 1977) for a period of five months and covering a 30- day pod storage period. During the investigation period, the daily storage conditions of temperature and relative humidity were recorded and fell within the range of $27.1-32{ }^{\circ} \mathrm{C}$ and $82 \%-93.6 \%$ respectively.

\subsection{Source of Pods for the Investigation}

Two hundred freshly harvested and similar physiologically matured pods were obtained from hand pollinated hybrids cocoa (Akokorabedi) at Fumso Cocoa Station in the Ashanti Region of Ghana. The pods were weighed using an electronic weighing scale to determine the weight of each pod,whilst a measuring tape was used to measure the length and girth (Centre,proximal anddistal ends) of the pods to ensure that uniform pod size were selected. These were subsequently stored for a period up to 30 days. The seeds were extracted from the stored pods and planted fresh whenever planting was due at every 5-day interval.

\subsection{Planting / Sowing of Seeds}

Three thousand, one hundred and fifty $(3,150)$ polythene bags of standard cocoa bag size $(12.5 \times 20)$ were used for the research. All of these bags were filled with solarized top soil. The filled polybags were arranged to form 3 replicates or blocks of the seven storage periods in a manner that ensured uniform sunlight entry across the blocks or replicates with a Randomized Complete Block Design, under an artificial shade of Bamboo post and palm frond matting, with an incident light intensity estimated to be about $30 \%$ full daylight.

The beans were planted with the mucilage (farmers' method) and were sown on their flat sides at the depth of about $2 \mathrm{~cm}$ below the surface of the planting media (top soil) after watering the soil a day before planting and so continued to the end of the experiment.

\subsection{Cultural Practices/Maintenance Regime}

Management practices such as weeding, watering, and pest control were carried out, with periodic treatment using an insecticide spray of "Akate Master" and separately complemented with Fungi-kill (fungicidal spray) during the 2-3 months post- emergence period.

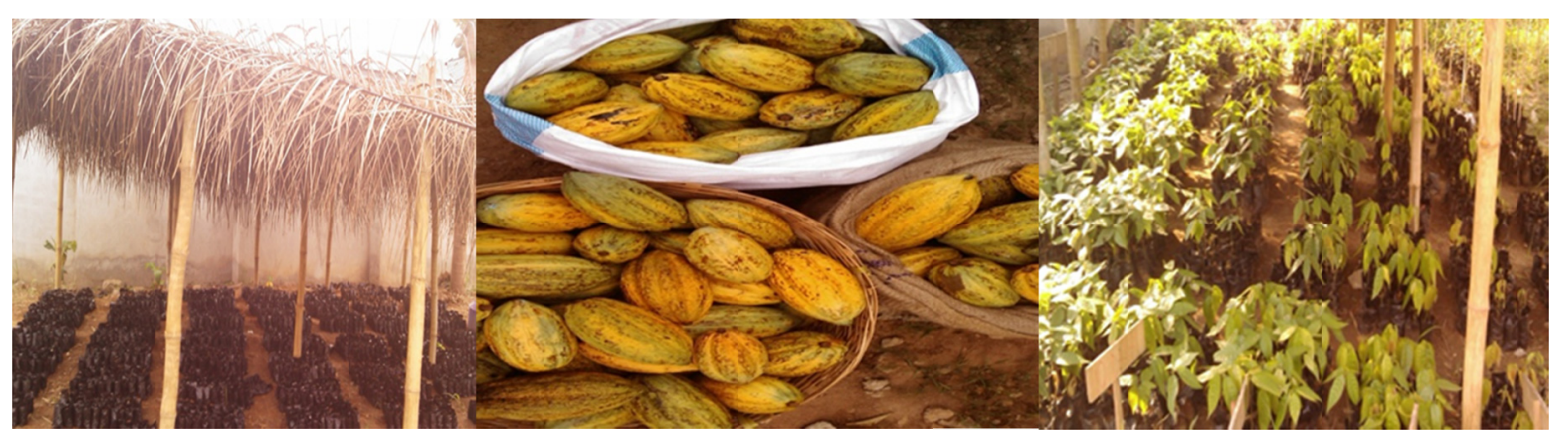

Figure 1. Pictorial presentation of the nursery establishment through the various stages 


\subsection{Parameters for Assessments}

Daily observation was carried out to note and record parameters essential to the research and at a time appropriate for each parameterdue for its assessment,which included, time (days) from sowing to start of germination, time (days) from start of germination to the final germination, time to drop cotyledons, germination percentage, speed of germinationand then seedling morphological data such as seedling vigour index, plant height, stem girth, number of leaves per plant, leaf area, leaf petiole length, stem nodes per plant, stem internode length, plant canopy spread, seedling root/ hypocotyl length and seedling dry weight (total dry matter, TDM) of hybrid Cocoa (AkokoraBedi).

These parameters of interest were categorized into germination- related parameters, comprising the first five (5) parameters stated above and then growth \& morphological-related parameter consisting of the remaining eleven (11) parameters. The latter set of parameters were assessed when the plants were 3 months old and were either measured directly or derived from well-proven formulae. Those parameters which were specifically derived using formulae were vigour index; estimated by adopting the formula as suggested by Abdul-Baki and Anderson (1973) viz:

Vigour index $=$ Germination (\%) $\mathrm{x}$ Seedling length $(\mathrm{cm})$; leaf Area, which was also estimated with an empirical relationship by Adenikiju's derived formula, (Adenikiju, 1974), viz:

$$
\mathrm{Y}=93.0+19.2 \mathrm{X}_{1}-124.4 \mathrm{X}_{2}+109.0 \mathrm{X}_{2}
$$

where $\mathrm{Y}=$ Leaf area; $\mathrm{X}_{1}=$ seedling height from ground to apex; $\mathrm{X}_{2}=$ leaf number per seedling; $\mathrm{X}_{2}=$ seedling age (weeks) after planting andthe last parameter was speed of germination of the sown seed which was alsoestimated using the following formula by Maguire (1962):

$$
\mathrm{SG}=\frac{\mathrm{N} 1}{\mathrm{D} 1}+\frac{\mathrm{N} 2}{\mathrm{D} 2}+\frac{\mathrm{N} 3}{\mathrm{D} 3}+\cdots+\frac{\mathrm{Nn}}{\mathrm{Dn}}
$$

Where,

$\mathrm{SG}=$ Speed of germination, N1, N2, N3..., Nn = Number of seedlings emerged on D1, D2, D3..., and Dn days after Sowing, respectively

All the other parameters / variables were measured directly using appropriate devices.

\subsection{Data Collection, Entry and Statistical Analysis}

Data collected were vigorously cross checked to ensure reliability, accuracy, completeness and consistency and subsequently analyzed with Statistical Analysis System (SAS) statistical package (Version 9.1), after transforming percentage and count data through Square Root Transformation. For simple factor effects, means were separated by Least Significant Difference (LSD)Test at $5 \%$ and significant differences were calculated and subsequently distinguished among means wherever, $\mathrm{P}<0.05$.

\section{Experimental Results}

\subsection{Interaction Effects}

The results of the research were analyzed in terms of the interactions effects of the two factors and then the simple effects of the factors, for significance or otherwise.

For the simple individual effects, means were differentiated with alphabets, where significant differences in means were exhibited, with the different alphabets or letters. It is worthy of note that this test controls the Type I comparison-wise error rate, but not the experiment-wise error rate.

Five variables had significant interactive effects and these included time taken to start germination; time taken from start to end of germination; seedling vigour index; plant shoot/ height and leaf area.

Outputs for these variables are as indicated in Tables 1, 2, 3, 4 and 5 as follows: 


\subsection{Interaction Tables}

Table 1. Interaction effects for time taken to start germination

\begin{tabular}{llll}
\hline Level of DAH & Level of Storage & Mean & Std Dev \\
\hline 0 & BASKET & 3.18 & 0.00 \\
0 & Fert_Sac & 3.23 & 0.09 \\
0 & Jute_Sac & 3.18 & 0.00 \\
5 & BASKET & 3.18 & 0.00 \\
5 & Fert_Sac & 3.18 & 0.00 \\
5 & Jute_Sac & 3.18 & 0.00 \\
10 & BASKET & 3.80 & 0.08 \\
10 & Fert_Sac & 3.75 & 0.00 \\
10 & Jute_Sac & 4.09 & 0.19 \\
15 & BASKET & 3.62 & 0.00 \\
15 & Fert_Sac & 3.71 & 0.08 \\
15 & Jute_Sac & 3.62 & 0.00 \\
20 & BASKET & 3.18 & 0.00 \\
20 & Fert_Sac & 3.42 & 2.08 \\
20 & Jute_Sac & 3.18 & 0.00 \\
25 & BASKET & 3.38 & 0.08 \\
25 & Fert_Sac & 3.33 & 0.00 \\
25 & Jute_Sac & 3.38 & 0.08 \\
30 & BASKET & 3.18 & 0.00 \\
30 & Fert_Sac & 3.18 & 0.00 \\
30 & Jute_Sac & 3.37 & 2.31 \\
\hline
\end{tabular}

Table 2. Interaction effects for time taken to end germination

\begin{tabular}{llll}
\hline Level of DAH & Level of Storage & Mean & Std Dev. \\
\hline 0 & BASKET & 3.42 & 2.31 \\
0 & Fert_Sac & 3.53 & 1.00 \\
0 & Jute_Sac & 3.53 & 0.08 \\
5 & BASKET & 3.74 & 3.40 \\
5 & Fert_Sac & 4.01 & 0.22 \\
5 & Jute_Sac & 3.23 & 0.08 \\
10 & BASKET & 3.83 & 2.52 \\
10 & Fert_Sac & 4.25 & 4.12 \\
10 & Jute_Sac & 2.59 & 2.65 \\
15 & BASKET & 2.90 & 0.10 \\
15 & Fert_Sac & 3.66 & 2.65 \\
15 & Jute_Sac & 3.77 & 3.24 \\
20 & BASKET & 3.58 & 3.56 \\
20 & Fert_Sac & 3.79 & 3.06 \\
20 & Jute_Sac & 3.83 & 2.52 \\
25 & BASKET & 4.29 & 0.07 \\
25 & Fert_Sac & 3.97 & 0.14 \\
25 & Jute_Sac & 3.77 & 3.04 \\
30 & BASKET & 4.33 & 0.06 \\
30 & Fert_Sac & 3.92 & 2.52 \\
30 & Jute_Sac & 3.83 & 2.08 \\
\hline
\end{tabular}


Table 3. Interaction effects for seedling vigour index

\begin{tabular}{llll}
\hline Level of DAH & Level of Storage & Mean & Std Dev. \\
\hline 0 & Basket & 15.90 & 0.89 \\
0 & Fert_Sac & 13.27 & 8.59 \\
0 & Jute_Sac & 18.51 & 2.73 \\
5 & Basket & 9.70 & 4.32 \\
5 & Fert_Sac & 15.46 & 7.75 \\
5 & Jute_Sac & 12.62 & 5.13 \\
10 & Basket & 6.88 & 1.93 \\
10 & Fert_Sac & 5.87 & 2.31 \\
10 & Jute_Sac & 2.05 & 1.58 \\
15 & Basket & 12.06 & 3.94 \\
15 & Fert_Sac & 8.94 & 5.35 \\
15 & Jute_Sac & 11.01 & 2.17 \\
20 & Basket & 10.84 & 1.05 \\
20 & Fert_Sac & 8.51 & 5.83 \\
20 & Jute_Sac & 12.26 & 3.38 \\
25 & Basket & 9.03 & 1.28 \\
25 & Fert_Sac & 7.85 & 1.39 \\
25 & Jute_Sac & 8.74 & 1.16 \\
30 & Basket & 9.18 & 1.11 \\
30 & Fert_Sac & 7.51 & 2.11 \\
30 & Jute_Sac & 9.42 & 2.39 \\
\hline
\end{tabular}

Table 4. Interaction effects for seedling shoot height

\begin{tabular}{llll}
\hline Level of DAH & Level of Storage & Mean & Std Dev. \\
\hline 0 & BASKET & 20.57 & 0.81 \\
0 & Fert_Sac & 19.20 & 3.77 \\
0 & Jute_Sac & 21.90 & 1.49 \\
5 & BASKET & 18.17 & 1.10 \\
5 & Fert_Sac & 20.13 & 4.92 \\
5 & Jute_Sac & 19.40 & 2.75 \\
10 & BASKET & 17.73 & 1.08 \\
10 & Fert_Sac & 16.53 & 3.62 \\
10 & Jute_Sac & 15.17 & 1.88 \\
15 & BASKET & 18.10 & 0.46 \\
15 & Fert_Sac & 17.33 & 2.06 \\
15 & Jute_Sac & 19.57 & 0.92 \\
20 & BASKET & 18.47 & 1.69 \\
20 & Fert_Sac & 18.17 & 4.26 \\
20 & Jute_Sac & 19.30 & 0.79 \\
25 & BASKET & 17.40 & 0.92 \\
25 & Fert_Sac & 17.00 & 2.17 \\
25 & Jute_Sac & 16.80 & 0.56 \\
30 & BASKET & 13.77 & 0.21 \\
30 & Fert_Sac & 13.43 & 1.12 \\
30 & Jute_Sac & 14.13 & 1.76 \\
\hline
\end{tabular}


Table 5. Interaction effects for seedling leaf area

\begin{tabular}{llll}
\hline Level of DAH & Level of Storage & Mean & Std Dev. \\
\hline 0 & Basket & 68.48 & 15.52 \\
0 & Fert_Sac & 125.81 & 18.42 \\
0 & Jute_Sac & 94.08 & 28.67 \\
5 & Basket & 113.47 & 76.35 \\
5 & Fert_Sac & 171.25 & 116.40 \\
5 & Jute_Sac & 170.48 & 52.79 \\
10 & Basket & 90.76 & 65.24 \\
10 & Fert_Sac & 115.44 & 69.55 \\
10 & Jute_Sac & 91.89 & 32.59 \\
15 & Basket & 145.52 & 8.80 \\
15 & Fert_Sac & 130.80 & 39.55 \\
15 & Jute_Sac & 173.68 & 17.74 \\
20 & Basket & 152.56 & 32.49 \\
20 & Fert_Sac & 146.80 & 81.78 \\
20 & Jute_Sac & 168.56 & 15.24 \\
25 & Basket & 256.48 & 17.60 \\
25 & Fert_Sac & 165.87 & 63.42 \\
25 & Jute_Sac & 162.03 & 61.96 \\
30 & Basket & 103.79 & 69.11 \\
30 & Fert_Sac & 180.99 & 21.05 \\
30 & Jute_Sac & 152.29 & 82.82 \\
\hline & & & \\
\hline
\end{tabular}

\subsection{Simple Germination-Related Variables}

\subsubsection{Time to Drop Cotyledon (Days)}

The time taken for the seedlings to shed their cotyledons, as a result of storage period, ranged between a minimum of 12 days to a maximum of 16 days, with a grand mean of 13.81 days.

However, these effects were insignificant as there were no significant differences in time taken to shed cotyledons by the seedlings throughout the storage period.

The effect of the storage containers was also insignificant, $(p>0.05)$ on time taken to shed or drop cotyledons (Basket, Jute sack, and Fertilizer sack).

\subsubsection{Germination Percentage}

Recorded range of germination percentage fell between a minimum of $6.7 \%$ to a maximum of $100 \%$, with a mean of 56.3095. Germination percentage recorded due to the effects of storage periods were found to be significantly different $(\mathrm{p}<0.005)$, at $5 \%$ level of significance. Specifically, there were significant differences among 10DAH \& $15 \mathrm{DAH}, 15 \mathrm{DAH} \& 20 \mathrm{DAH} 10 \mathrm{DAH} \& 25 \mathrm{DAH}$, with $25 \mathrm{DAH}$ producing a germination percentage of $17.8 \%$ higher than the effects of 10DAH.

There were however no significant differences $(\mathrm{P}>0.05)$ in percentage germination due to storage containers.

\subsubsection{Speed of Germination}

The minimum speed recorded for germination was 0.13 whilst the maximum speed was 4.58 , with a mean of 2.017 . The storage effect of 10 DAH was significantly different from the effects of 0 DAH \&15 DAH. 15 DAH \& 20 DAH were also significantly different. There were no significant differences within the set 15 DAH to 30 DAH. The pods stored for 0 days recorded numerically higher (2.8011) speed of germination and therefore germinated faster compared to 5 -day storage (2.4678) to 20 -day storage (2.2056) and through to 10 - day of storage (0.8867). 
In contrast, there was no significant influence of storage containers on the speed of germination of the seedlings.

\subsection{Growth \&Morphological Variables}

\subsubsection{Seedling Stem Girth/ Diameter (cm)}

Seedling stem diameter measured with a Venier calipers ranged between $0.28 \mathrm{~cm}$ and $0.44 \mathrm{~cm}$ with an overall mean of $0.3658 \mathrm{~cm}$ at 3 months old, but there were no significant differences ( $>0.05)$, on seedling stem diameter, as p-value was 0.0789 .

This variable was also not-significantly influenced by containers $(\mathrm{p}>0.05)$.

\subsubsection{Number of Leaves per Plant}

The number of leaves produced per plant at the 3months ranged between 2.11 and 2.45 with an overall mean of 2.25 leaves per seedling. There was significant difference in leaf production as a result of storage period effects: the effects of $10 \mathrm{DAH}$ on leaf production were significantly different from the other remaining DAH effects, with 0 DAH for instance being 3.9\% higher than $10 \mathrm{DAH}$.

But there were no significant differences $(\mathrm{P}>0.05)$ in number of leaves per plant, due to the effects of storage containers (Basket, Jute sack and Fertilizer sack)

\subsubsection{Leaf Petiole Length $(\mathrm{cm})$}

Seedling /plant leaf petiole length as presented in Table $6 \mathrm{~b}$ show significant variability in storage period effects $(\mathrm{p}<0.05)$, as the $\mathrm{p}$-value of 0.0080 is less than 0.05 . The $0 \mathrm{DAH}$ storage period effect was significantly different from the set of $5 \mathrm{DAH}-30 \mathrm{DAH}$, on petiole length.Petiole length of seedlings from pods of 0 days storage was $3.02 \mathrm{~cm}$ at 3 months old and produced $19.3 \%$ higher effects in respect of the LSD value. It was also $0.489 \mathrm{~cm}$ and $16.2 \%$ longer than petiole length produced by plants from pods stored for 20 days, which in turn was $1.00 \mathrm{~cm}$ longer than plants from pods stored for 5 days.

However, there were no significant differences recorded forpetiole length among seedlings obtained from pods stored in any of the containers $(\mathrm{p}>0.05)$.

\subsubsection{Stem Nodes per Plant}

The number of nodes per seedling was found to be significantly different, as the p-value of 0.0042 is less than 0.05 $(\mathrm{P}<0.05)$, due to the effects of number of days pods were stored. Effects of 30DAH were significantly different from the effects of $0 \mathrm{DAH}, 5 \mathrm{DAH}, 10 \mathrm{DAH}, 15 \mathrm{DAH}, 20 \mathrm{DAH}$ and $25 \mathrm{DAH}$, within which set there were no significant differences.

Stem nodes per plant,resulting from podsstored for 20 days was 6.56 and 0.67 higher than that produced by plants from pods stored for $10 \& 15$ days, which in turn was 0.44 higher than plants from pods stored for $0,5 \& 25$ days.

On the other hand, the number of nodes per seedling resulting from the effects of storage containers used for the pod storage (Basket, Jute sack and Fertilizer sack) was found to have insignificant differences $(P>0.05)$.

\subsubsection{Stem Internode Length $(\mathrm{cm})$}

Seedling internode length of $T$. cacao as a result of the seven periods for which the pods were stored (seven storage periods) at $5 \%$ level of significance was measured. Results of the effects of storage period (DAH), was insignificant (p: $0.2209>0.05$ ).

On the contrary, Plants from pods stored in Basket, Jute sack and Fertilizer sack differed significantly in internode lengths. The effects of Basket storage were significantly different from the effects of fertilizer storage (a difference of $0.28 \mathrm{~cm}$; which is $38.5 \%$ higher than the LSD value of 0.2029 ) but $23.5 \%$ longer than the internode length produced by fertilizer sack pod seedlings. Jute sack effect was also different from Fertilizer sack.

\subsubsection{Plant Canopy Spread (cm)}

There was significant difference in Seedling canopy spread of plants ( 3 months old) from pods stored for the various storage periods $(p<0.05)$. Effects of 30 day storage were significantly different $(25.7 \%$ and $20.9 \%$ respectively lower and narrower) from those of 0 day storage and 20 day storage.

However, plants from pods stored in Basket, Jute sack and Fertilizer sack did not produce significant differences in canopy spread $(\mathrm{p}>0.05)$.

\subsubsection{Seedling Root/ Hypocotyl Length $(\mathrm{cm})$}

Root length was significantly influenced $(\mathrm{p}<0.05)$ by storage periods.Root length of seedlings resulting from 15 DAH, 25 DAH and 30 DAH were significantly different from the mean of seedlings for 0 DAH, 5 DAH 10 DAH 
and $20 \mathrm{DAH}$. Root length of seedlings produced from 0 DAH were thus $23 \%$ longer than that of $25 \mathrm{DAH}$ seedlings, whilst 10D AH seedlings was $19.4 \%$ longer than that of $25 \mathrm{DAH}$. It was observed that numerically, pods stored for zero days of storage produced seedlings with longest root length of $9.79 \mathrm{~cm}$ whilstthe shortest root length was recorded by seedlings frompods stored for $25 \mathrm{DAH}(7.7133 \mathrm{~cm})$.

This parameter was non-significantly influenced $(\mathrm{p}>0.05)$ by containers throughout the storage period of 0 up to 30 day's storage.

\subsubsection{Seedling Dry Weight (Total Dry Matter- g/seedling)}

Pods stored for 15DAH produced plants with the highest TDM of $4.9022 \mathrm{~g} /$ seedling, whilst pods stored for 0DAH produced plants with the lowest TDM of $2.9033 \mathrm{~g} /$ seedling, but was not significantly influenced ( $\mathrm{p}>0.05$ ) by storage periods.

Contrary to this, the influence of containers on TDM (dry weight) of seedlings was significant $(p<0.05)$ at $5 \%$ level of significance, as in Basket and Fertilizer sack storage effects. The effects of Basket storage thus resulted in $41.9 \%$ accumulation of dry matter above that of Fertilizer sack storage as indicated in Table $1 \mathrm{~b}$ below:

Table 6a. Effects of storage period on 16 variables of the experiment

\begin{tabular}{lllllll}
\hline \multirow{2}{*}{ Source } & \multicolumn{7}{c}{ Means of Variables } \\
\cline { 2 - 7 } & Cotyledon Shed & Germ Pct & Germ Speed & Vigour Index & Stem Girth & Leaves/Plt \\
\hline $0 \mathrm{DAH}$ & $3.78 \mathrm{a}$ & $4.29 \mathrm{a}$ & $2.80 \mathrm{a}$ & $15.89 \mathrm{a}$ & $0.35 \mathrm{a}$ & $2.42 \mathrm{a}$ \\
$5 \mathrm{DAH}$ & $3.79 \mathrm{a}$ & $4.11 \mathrm{a}$ & $2.47 \mathrm{a}$ & $12.59 \mathrm{a}$ & $0.36 \mathrm{a}$ & $2.28 \mathrm{~b}$ \\
$10 \mathrm{DAH}$ & $3.71 \mathrm{a}$ & $3.99 \mathrm{a}$ & $0.89 \mathrm{~b}$ & $4.93 \mathrm{~b}$ & $0.39 \mathrm{~b}$ & $2.33 \mathrm{~b}$ \\
$15 \mathrm{DAH}$ & $3.72 \mathrm{a}$ & $3.22 \mathrm{~b}$ & $1.88 \mathrm{c}$ & $10.67 \mathrm{c}$ & $0.38 \mathrm{a}$ & $2.26 \mathrm{bc}$ \\
$20 \mathrm{DAH}$ & $3.68 \mathrm{a}$ & $3.95 \mathrm{ac}$ & $2.21 \mathrm{ac}$ & $10.54 \mathrm{c}$ & $0.37 \mathrm{a}$ & $2.26 \mathrm{c}$ \\
$25 \mathrm{DAH}$ & $3.66 \mathrm{a}$ & $3.92 \mathrm{c}$ & $1.69 \mathrm{c}$ & $8.54 \mathrm{c}$ & $0.35 \mathrm{a}$ & $2.13 \mathrm{~d}$ \\
$30 \mathrm{DAH}$ & $3.74 \mathrm{a}$ & $4.13 \mathrm{c}$ & $2.19 \mathrm{c}$ & $8.70 \mathrm{c}$ & $0.36 \mathrm{a}$ & $2.10 \mathrm{~d}$ \\
CV & 4.05 & 8.87 & 36.07 & 36.56 & 9.52 & 3.58 \\
LSD & 0.14 & 0.33 & 0.69 & 3.5762 & 0.03 & 0.07 \\
\hline
\end{tabular}

Means with the same letter are not significantly different within a column.

Table $6 \mathrm{~b}$. Effects of storage period on 16 variables of the experiment (cont.)

\begin{tabular}{lllllll}
\hline \multirow{2}{*}{ Source } & \multicolumn{7}{c}{ Means of Variables } \\
\cline { 2 - 7 } & Petiole Length & Nodes/Plant & Internode Length & Canopy Spread & Root Length & Dry Matter \\
\hline $0 \mathrm{DAH}$ & $3.02 \mathrm{a}$ & $5.44 \mathrm{a}$ & $1.40 \mathrm{a}$ & $23.67 \mathrm{a}$ & $9.79 \mathrm{a}$ & $2.90 \mathrm{a}$ \\
$5 \mathrm{DAH}$ & $2.43 \mathrm{~b}$ & $5.44 \mathrm{a}$ & $1.12 \mathrm{a}$ & $18.91 \mathrm{~b}$ & $9.01 \mathrm{a}$ & $3.64 \mathrm{a}$ \\
$10 \mathrm{DAH}$ & $2.42 \mathrm{~b}$ & $5.89 \mathrm{a}$ & $1.49 \mathrm{ba}$ & $22.11 \mathrm{ba}$ & $9.21 \mathrm{a}$ & $3.78 \mathrm{a}$ \\
$15 \mathrm{DAH}$ & $2.23 \mathrm{~b}$ & $5.89 \mathrm{a}$ & $1.39 \mathrm{~b}$ & $21.09 \mathrm{~b}$ & $8.57 \mathrm{ab}$ & $4.90 \mathrm{ac}$ \\
$20 \mathrm{DAH}$ & $2.53 \mathrm{~b}$ & $6.56 \mathrm{a}$ & $1.48 \mathrm{ba}$ & $22.78 \mathrm{~b}$ & $9.16 \mathrm{a}$ & $3.31 \mathrm{~b}$ \\
$25 \mathrm{DAH}$ & $2.41 \mathrm{~b}$ & $5.44 \mathrm{ba}$ & $1.29 \mathrm{~b}$ & $19.72 \mathrm{~b}$ & $7.71 \mathrm{~b}$ & $3.54 \mathrm{ba}$ \\
$30 \mathrm{DAH}$ & $2.24 \mathrm{~b}$ & $4.88 \mathrm{~b}$ & $1.27 \mathrm{~b}$ & $18.83 \mathrm{bc}$ & $8.10 \mathrm{~b}$ & $3.91 \mathrm{ba}$ \\
CV & 17.41 & 14.21 & 24.14 & 17.59 & 11.76 & 42.29 \\
LSD & 0.41 & 0.76 & 0.31 & 3.52 & 0.98 & 1.49 \\
\hline
\end{tabular}

Means with the same letter are not significantly different within a column. 
Table 7a. Effects of storage containers on the 16 variables of the study

\begin{tabular}{lllllll}
\hline \multirow{2}{*}{ Source } & \multicolumn{7}{c}{ Means Of Variables } \\
\cline { 2 - 7 } & Cotyledon Shed & GermPct & GermSpeed & PltHeight & StemGirth & Leaves/Plt \\
\hline BASKET & $3.69 \mathrm{a}$ & $4.05 \mathrm{a}$ & $2.12 \mathrm{a}$ & $17.74 \mathrm{a}$ & $0.37 \mathrm{a}$ & $2.26 \mathrm{a}$ \\
JUTESACK & $3.73 \mathrm{a}$ & $3.91 \mathrm{a}$ & $2.04 \mathrm{a}$ & $18.03 \mathrm{a}$ & $0.36 \mathrm{a}$ & $2.26 \mathrm{a}$ \\
FERTSACK & $3.76 \mathrm{a}$ & $3.89 \mathrm{a}$ & $1.88 \mathrm{a}$ & $17.40 \mathrm{a}$ & $0.35 \mathrm{a}$ & $2.23 \mathrm{a}$ \\
CV & 4.04 & 8.87 & 36.08 & 12.14 & 9.52 & 3.57 \\
LSD & 0.09 & 0.22 & 0.45 & 1.34 & 0.02 & 0.05 \\
\hline
\end{tabular}

Means with the same letter are not significantly different within a column.

Table $7 \mathrm{~b}$. Effects of storage containers on the 16 variables of the study

\begin{tabular}{lllllll}
\hline \multirow{2}{*}{ Source } & \multicolumn{7}{c}{ Means of Variables } \\
\cline { 2 - 7 } & PetioleLength & Nodes/Plant & InternodeLength & CanopySpread & RootLength & DryMatter \\
\hline BASKET & $2.37 \mathrm{a}$ & $5.52 \mathrm{a}$ & $1.47 \mathrm{a}$ & $22.11 \mathrm{a}$ & $8.89 \mathrm{a}$ & $4.37 \mathrm{a}$ \\
JUTE SACK & $2.57 \mathrm{a}$ & $5.80 \mathrm{a}$ & $1.37 \mathrm{a}$ & $21.12 \mathrm{a}$ & $8.85 \mathrm{a}$ & $3.68 \mathrm{a}$ \\
FERT SACK & $2.48 \mathrm{a}$ & $5.62 \mathrm{a}$ & $1.19 \mathrm{ab}$ & $19.80 \mathrm{a}$ & $8.63 \mathrm{a}$ & $3.07 \mathrm{ab}$ \\
CV & 17.40 & 14.21 & 24.14 & 17.58 & 11.75 & 42.26 \\
LSD & 0.26 & 0.50 & 0.20 & 2.30 & 0.64 & 0.97 \\
\hline
\end{tabular}

Means with the same letter are not significantly different within a column.

\section{Results and Discussion}

\subsection{Interaction Effects (Storage Period x Containers) on Experimental Variables}

Generally, five (5) out of the sixteen (16) experimental parameters/ variables representing $31.25 \%$ of the total number variables recorded significant interactions (as each of those variables had $\mathrm{p}<0.05$, upon assessing their Analysis of Variance, ANOVA) between storage period and storage containers but these interactions were not affected by storage conditions of temperature and relative humidity of $27.1^{\circ} \mathrm{C}-32^{\circ} \mathrm{C}$ and $82 \%-93.6 \%$ respectively. Thus, more than half of the total experimental variables did not record significant interactions.

Out of this $31.25 \%$ that was significant, specifically, $40 \%$ ( 2 out of 5 ) of germination related variables recorded significant interactions. The two, are: the time taken by the seed to start germination and time taken to end germination.

The interactions resulted in a reduction of the time taken for the sowed seed to start germination and also reduced the time taken from start of germination in a lot to completion of germination within the same lot (as compared with the two simple individual effects) Hence the interactions reduced the number of days that seed from pods stored in Fertilizer sack and Jute sack would have taken to germinate.

This situation could be accounted for by the effect of internal respiration within the pod, which metabolic process may not have reached a level so high as to reduce the bean size within the first ten days of storage and therefore did not affect the surface area of the bean. The large surface area may have resulted in higher imbibitions rate to increase the metabolic activity within the bean (Dwapanyin \& Frimpong, 2003). This subsequently resulted in faster germination, reducing the time associated with the germination process.

The relatively shorter time taken from start to end of germination could be due to greater food reserves within the bean, at the early part of the storage, which was catalyzed and metabolized to provide the needed energy to quicken the germination process. However with continued storage, the stored food reserves in the beans could have been used up through respiration during germination and therefore could not be readily available for the seedling to emerge when storage was delayed (Olympio \& Kumah, 2009).

On the growth and morphological variables, three (3) out of the eleven (11) variables also recorded significant interactions. They included seedling vigour index, stem height or length and seedling Leaf Area. 
Seedling vigour was significant because most of the seedlings retained their cotyledons for some time and that provided the seedlings with food reserves for growth activities, which were later complemented by the high photosynthetic activity as a result of the higher leaf area of the seedling. Therefore, it is evident from the resultsthat storing cocoa pods in the three containers for a period up to 30 days, particularlyearly days storage (0-10) in Jute sack and Fertilizer, lead toresponses that help build vigour in the resulting seedlings.

Focusing on Plant height, superior performance was produced during the early days of storage, which indicates that the seedlings were protected against detrimental physiological and biochemical changes. These could be attributed to the high seedling vigour observed and the presence of cotyledons at the early growth stage, which could have served as sources of food reserves for active growth, and consequently resulted in more photosynthetic activities. These results could also mean that seedlings channeled the photosynthates produced towards height, internodes, petiole and leaf development. The utilization of photosynthates for these structural developments, as influenced by the environment was reported by Gardner et al. (1985).

Leaf Area, as earlier indicated, was found to be significantly influenced by storage period and container interactions. The interactions resulted in larger leaf area above that produced by the separate simple effects of the individual storage factors (storage period and storage container). The larger leaf area of the seedlings thus resulted in greater exposure to solar radiation for photosynthate production, seedling vigour and rapid dry matter accumulation. Leaves enlarged, elongated and produced more chlorophyll per unit area to compensate for the loss in numbers, so as to improve photosynthetic activities (Ndubuaku et al., 2000). These findings were also similar to those observed by Ahenkora and Halm (1977). In all these, pod storage conditions of $27.1-32^{\circ} \mathrm{C}$ and relative humidity of $82 \%-93.6 \%$ did not have any effect, as correlation analysis run showed non-significant effects.

In sum, these interactions resulted in superior performance of these five variables or parameters than did the individual factors of storage period and storage containers.

\subsection{Simple Effect of Germination-Related Variables}

The 0DAH - 10DAH storage beans recorded higher percentage germination than 15DAH- 30DAH stored beans. The lower percentage and speed of germination in the 15DAH -30DAH stored beans could be due to increase in metabolic activity which lead to increased respiration rate and utilization of food reserves (Meena et al., 1998). This situation could be due to the activities of microbial organisms which were attracted to the beans as a result of the mucilage. It could also be due to the inhibitory effect of the seed mucilage which delayed germination and subsequently led to the death of some of the beans in the soil as earlier observed by Ashiru (1970). The higher and faster rate of germination (speed of germination) generally obtained in respect of $0 \mathrm{DAH}-10 \mathrm{DAH}$ could be attributed to the available food reserves utilized by the growing seedling as compared with the $15 \mathrm{DAH}-30 \mathrm{DAH}$ which did not have ready access to the stored food reserves due to exhaustion of food reserves or specific metabolic substrate necessary to provide energy for early stage of germination before digestion of food reserves begins. Similar observations were made by Ndubuaku and Lucas (1986) and Ndubuaku and Oyekanmi (2000). Another possibility could be due to the loss of enzyme activity needed to catalyze germination, though it was found by other authorities that dead seeds sometimes contain some active enzymes (Stone, 1957a).

\subsection{Simple Effect of Growth \& Morphological Variables/ Parameters}

Cocoa seedling growth parameters studied in this experiment varied significantly $(\mathrm{p}>0.05)$ due to pod storage period.Seedlings from $0 \mathrm{DAH}$ and $5 \mathrm{DAH}$ storage produced bigger stem girth, nodes per plant, more leaves per plant with longer petiole length, internode length. A similar trend was also exhibited by seedlings from the various storage periods in respect of seedling canopy spread, which were higher for $0 \mathrm{DAH}$, then low for 5DAH, then higher again 10DAH-20DAH and subsequently declined. These situations in respect of these experimental variables were irrespective of the storage conditions of $27.1-32{ }^{\circ} \mathrm{C}$ and relative humidity of $82 \%-93.6 \%$. These could be attributed to the high seedling vigour and the presence of cotyledons at the early growth stage, which could have served as sources of food reserves for active growth, and consequently resulted in more photosynthetic activities. Cantliffe (1998) reported of similar findings in his work.

These results could also mean that seedlings raised from pods stored for 0 DAH -10 DAH channeled the photosynthates towardsgirth, nodes, internode and leaf development. The utilization of photosynthates for these structural developments, as influenced by environmental growth conditions, was reported by Gardner et al. (1985).

The general reduction of stem diameter/girth, internode length, height, Leaf number per plant, petiole length, nodes per plant for the longer storage periods could be as a result of slowed growth and possibly reduced photosynthetic rates. The little metabolite produced is usually used for maintenance respiration more than vegetative growth. (Ndubuaku \& Ndubuaku, 2001). However, internode length was significantly influenced by the 
type of storage container. Basket storage produced the significantly longest internode length from Fertilizer sack storage.

This could be due to the non-accumulation of deleterious products of respiratory activities of pods (Carbon IV Oxide $\left(\mathrm{CO}_{2}\right)$ and Heat) within the storage container (Basket), hence the slightly superior performance of seedlings internode length.

The root or hypocotyl length for the storage period was generally longer for the storage periods $0 \mathrm{DAH}-20 \mathrm{DAH}$, albeit in a reducing order. The production of longer root length for the early days ofstorage could be a physiological effort to develop longer radiclethatcould support the plant to absorb minerals for general growth of the plant. Conversely, root/hypocotyl length decrease with long storage period in cocoa pods is similar to the observation in seedlings of Pinusthunbergii and P. rigida (Kim et al., 1978)

Length of storage did not affect significantly,dry matter accumulation in seedlings from the pods stored for the respective periods, but was significantly influenced by the type of container used to store the pods. The relatively higher accumulation of weight for the $0 \mathrm{DAH}$ to $15 \mathrm{DAH}$ from basket storage could bepossibly due to the initial early and active germination and growthof the seedlingsfor such storage periods, which helped to start early accumulation of dry matter, and this agrees with the observations made in Eucalyptus citriodora (Aguiar \& Nakane, 1983) and in Pisum sativum (Kant, 1986).

\section{Conclusion}

Seed from pods stored from 0 DAH - 15 DAH generally produced superior performance in most of the germination-relatedparameters measured, and therefore had maximum viability within this range, than seeds from pods stored from $15 \mathrm{DAH}$ - $30 \mathrm{DAH}$. Superior performance was not significantly different among seedlings produced within the 0 DAH - 15 DAH storage. Growth and morphological properties of the seedlings obtained were also higher within the range of $0 \mathrm{DAH}-20 \mathrm{DAH}$ storage period.

In terms of the traditional storage containers used, (i.e. Basket, Jute sack and Fertilizer sack), there were no significant differences in performance for almost all the variables (except Internode length and dry matter) even though basket storage produced relatively higher superior performance.

\section{Recommendation}

1. Farmers should continue carting and/or storing cocoa pods in their traditional storage containers of Basket, Jute sack or Fertilizer, as those containers do not have any significant differences in effect.

2. The hybrid pods meant for propagation ideally should be planted within 0-15 DAH for maximum viability.

3. Management of Cocoa Industry (e.g. Ghana Cocoa Board) should ensure adequate and even distribution of Gardens (Cocoa Stations) to prevent farmers holding harvested pods beyond 15 days after harvest.

\section{Acknowledgements}

The completion of this work would not have been possible without the hand of God Almighty.Lecturers and staff of the Department of Horticulture, Kwame Nkrumah University of Science and Technology, Kumasi, Ghana, who in diverse ways contributed to aspects of this work, are also acknowledged.

Dr. Bonaventure Aligbam, a Research Fellow at the College of Agriculture and Consumer Sciences of University of Ghana, who read and offered some suggestion on some aspects of the work, also deserve acknowledgement.

Sincere thanks also go to Mrs. Agnes Ankomah, a Biometrician with the Crops Research Institute of Ghana (Council for Scientific and Industrial Research) at Fumesua, near Kumasi, for supporting in the statistical analysis of the work.

The contribution of Mr. Emmanuel Odame Anti (CSSVD Control Unit, COCOBOD) is also appreciated.

The special roles played by the publishers of this work, who provided a platform for the work to get to the reading public are also duly acknowledged for their support.

Finally, all well-wishers whose names have not been directly mentioned, but who have been associated with this work in one form or the other is duly acknowledged and appreciated.

\section{References}

Abdul-Baki, A. A., \& Anderson, J. D. (1973). Vigour determination in soybean by multiple criteria. Crop Sci., 13, 630-633. http://dx.doi:2135/cropsci1973.0011183x0013000600013x

Adenikiju, S. A. (1974). Analysis of growth patterns in Cocoa seedlings as influenced by bean maturity. Exper. Agric, 10, 141. http://dx.doi.org/10.1017/s0014479700009558 
Agrawal, P. K. (1995). Seed Storage and Packaging. In P. K. Agrawal \& M. Dadlani (Eds.), Techniques in Seed Science and Technology (2nd ed., pp. 159-163). New Delhi: South Asians Publishers.

Aguiar, I. B. de, \& Nakane, J. T. (1983). Seed size of Eucalyptus citriodora: influence on germination and vigour. BrasilFlorestal, 13(53), 25-28.

Ahenkora, Y., \& Halm, B. J. (1977). Cocoa bean viability during pod storage and seedling performance in nursery.A publication of the Cocoa Research Institute of Ghana, New Tafo. Ghana J. Agric. Sci., 8, 4-8.

Anon. (1977). Agric. Extension Handbook by Ghanaian German Agric. Development in the Northern and Upper East Regions of Ghana-Tamale, 15(33), 108119.

Ashiru, G. A. (1970). Viability of cocoa beans. Experimental Agric., 6, 341-344. http://dx.doi.org/10.1017/S0014479700009820

Cantliffe, J. D. (1998). Seed Germination for Transplants. Hort. Technology, 8(4). Florida Agricultural Experiment Station Journal Series N-01421.

Chinwuku, U. M., \& Lucas, E. O. (1986). The Effect of different particle sizes of saw dust and forest topsoil on germination, growth and development of two cocoa varieties in the nursery. Turrialba, 36(3), 307-314.

Dwapanyin, A. O., \& Frimpong, E. B. (2003). The Effects of Bean Size and Shade on the growth and development of Nursery Cocoa Seedlings. 15 ${ }^{\text {th }}$ International Cocoa Research Conference Report (pp. 110-180). Retrieved from www.copal-cpa.org

Gardner, P. F., Pearce B. R., \& Mitchell, L. R. (1985). Physiology of Crop Plants (pp. 221-225). AMES: Iowa State University Press.

ISSER. (2003). State of the Ghanaian Economy. Institute of Statistical, Social and Economic Research (ISSER), University of Ghana, Legon, Accra, Ghana.

Kant, K. (1986). Effects of location and grading on emergence and subsequent plant performance in pea (Pisum sativum). Seed Research, 14(1), 102-110.

Kim, K. S., Kwon, H. M., Choi, S. K., \& Tak, W. S. (1978). Effects of seed size of two pine species on early seedling growth. Research Report of the Institute of Forest Genetics, 23, 73-77. Korea Republic.

Maguire, J. D. (1962). Speed of Germination, Aid in Selection Evaluating for Seedling Emergence and Vigour. Crop Sci., 2, 176-177. http://dx.doi.org/10.2135/cropsci1962.0011183X000200020033x

Ndubuaku, U. M., \& Ndubuaku, T. C. N. (2001). Effects of Bean Condition and Sowing Media on Germination and Nursery Performance of some selected Theobroma cacao L. Genotypes. $14^{\text {th }}$ International Cocoa Research Conference Report (pp. 116-134). Retrieved from www.copal-cpa.org

Ndubuaku, U. M., \& Oyekanmi, E. O. ( 2000). Preliminary effect of saw dust/ topsoil mixtures on germination, root volume and other growth parameters of F3 Amazon cocoa seedlings in the nursery. Niger. J. Sci., 34(4), 388-393.

Olympio, S., \& Kumah, P. (2009). Postharvest Physiology of Horticultural Crops, KNUST Press.

Onakoya, O. A. (2011). Germination and Growth Performance of Cocoa (Theobroma Cacao L.) Seedlings As Influenced by the Position of Beans in the Pod. Thesis submitted to the Department of Horticulture, College of Plant Science \&Crop Production, University of Agriculture, Abeokuta, Ogun State.

Oti-Boateng. (2001). The storage of tropical agricultural products Post-harvest Management Group. Compendium on Post-harvest Operations. Higher Education Commission, Pakistan. 2009

Redshaw, E. T. (1965). Studies on the effects of Cold on cocoa seeds; Inter-American Institute of Agricultural Sciences of the OAS, Training and Research Centre, Turrialba, Costa Rica.

Robbins, J. M. A., \& Shrestha, B. N. (1986). NR Study -Note 120 C. Tree Seed Processing and Treatment. No 11.HMG/EEC/ODA. National Tree Seed Project. HMG/UNDP/FAO Community Forestry Development Project.

Snedecor, G., \& Cochran, W. G. (1967). Statistical Methods (pp. 135-197). Oxford and IBH Publishing Company, Bombay.

Stone, E. C. (1957a). Embryo dormancy and embryo vigour of sugar pine as affected by length of storage and storage temperatures. Forest Sci., 3, 357. 
Vanangamudi, K., Karivaratharaaju, T., Balakrishnan, V., \& Maallika, K. (1988). Physical, Physiological and bio-chemical evaluation of graded seeds of pigeon pea cultivars. Madras Agricultural Journal, 75(5-6), 228-230.

\section{Copyrights}

Copyright for this article is retained by the author(s), with first publication rights granted to the journal.

This is an open-access article distributed under the terms and conditions of the Creative Commons Attribution license (http://creativecommons.org/licenses/by/3.0/). 